\title{
Regional Models on Managing the Public-Private Partnership Projects in Housing and Communal Complex
}

\author{
Kristina E. Filushina \\ Julia A. Kolyhaeva \\ Nikolay N. Minaev \\ Olga I. Dobrynina \\ Julia A. Merkuleva \\ Tomsk State University of architecture and building, Russian Federation \\ Email: kri1617@yandex.ru
}

\section{Doi:10.5901/mjss.2015.v6n3s5p55}

\section{Abstract}

Due to the crisis in Russia and the lack of sufficient financial resources, the problem of interaction between the state and the subjects of housing and communal services in the regions is rather urgent and requires an elaboration of an effective management model of public-private partnerships. The purpose of this article is to develop a management model of publicprivate partnership in the housing and utilities sector. Using econometric analysis methods, authors of this paper have analyzed regional projects of public-private partnership in housing and communal complex. The basic models and mechanisms of interaction were identified, a new scheme of interaction between the subjects of public-private partnerships were developed. These developments can be applied in the territorial and sectoral planning scheme, as well as in regional development programs of various regions. The significance of this article is defined by the fact that applying the developed models of publicprivate partnerships the responsibilities and risks between the subjects of PPP projects can be divided. Increased interaction with the state will increase the number of social projects, enable to extend the implementation of existing projects, as well as give financial stability of the newly created infrastructural projects and provide them with the necessary governmental guarantees.

Keywords: housing and communal services, public-private partnership models, project management, regional governance

\section{Introduction}

The use of public-private partnerships (PPP) in regional projects in the field of public infrastructure, social and municipal services is widespread throughout the world. The world experience shows that PPP is one of the most effective mechanisms for solving problems in the field of housing and communal services (i.e. public utility). In Russia, the interaction of government and business began long ago, and was aimed at solution of social problems, respectively, housing and communal services was no exception in this regard. However, the scientific community has largely neglected this phenomenon. Existing models of public infrastructure governance cannot be considered effective, as actors do not have sufficient interests in improving the quality of services and apply infrastructure upgrades. Another big problem is the lack of funding, as the costs cannot be sufficiently compensated by the consumers due to the effects of the tariff system for determining prices, while the municipal budget is not able to bear the necessary costs.

The interactions between the state and the private entities over the socially significant projects are generally entitled as public-private partnership (PPP). The most popularity this interaction has received in recent years, due to the unstable situation in the country, while for potential investors providing the opportunity to reduce costs and divide the upcoming risks (Filushina, 2012a). Figure 1 suggests an outline of the implementation of PPP scheme in the public utility sector. 


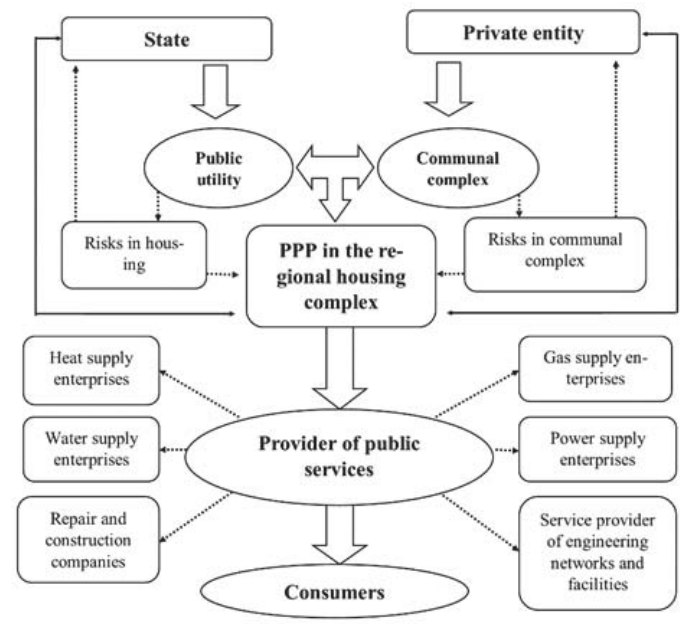

Figure 1. Implementation of PPP scheme in the public utility sector

The main feature of the interactions shown in Figure 1 is the fact that PPP helps not only in the development of regional public utility sector, but it enables to devide the emerging risks as in housing and utilities sector. PPP is the connecting link between all stakeholders of public services, namely the manufacturers of utility services and consumers of those services (Filushina, 2014). Major advantages of the PPP for the state are:

- Reduction in government spending on construction, operation and maintenance of the objects of partnership;

- Sharing of risks between the authorities and subject public utility (see Filushina, 2011);

- Attraction of private investments in public facilities;

- Reducing the need for public administration by delegating the control and governance functions to the subject of public services (namely the housing sector);

- Reduce public funding;

- Meeting the needs of the population at the expense of financing socially significant projects;

- Possibility to make use of modern technologies;

- Improving the investment attractiveness of regions;

- Possibility of obtaining long-term socially-significant projects as partners;

Major advantages of the PPP for the public utilities (Filushina, 2012b; Minaev, 2014):

- Stable competitiveness of business;

- Improving the image of the subject of the public utility at the regional, national and often the international level;

- Creation of additional development capacity, both by increasing public funding and by the possibility of attracting new technologies;

- State assistance at the implementation of long-term, large-scale, underperforming projects with a long payback period.

\section{Overview of Scientific Publications on the Management of PPPs}

The most common definition of public-private partnership (PPP) has given Varnavskiy (2005): public-private partnership is an institutional and organizational alliance between government and business in order to implement socially important projects and programs in a wide range of industries and R\&D, down to services. Definition of Varnavskiy is quite general, thus, it can serve as a basis for a broad understanding of PPPs. Nevertheless, unfortunately, it does not disclose the essence of PPP projects is in housing and communal services in the region. Under the proposed definition, any joint activity of the government and business can be considered as a public-private partnership.

Public-private partnership is an element (according to the approach O'Toole, 1997) and a variety of political networks - networks of producers (in accordance with the classification of Rhodes \& Marsh, 1992), so it is characterized by a complete set of signs of the type of interaction between the government and social structures. 
Yakunin (2007) suggests that as any political network, the PPP is based on a uniting common interest of its members. "Consumables" that is focused on the costs of security sphere and development interests of the state and "profitable", focused primarily on profit, business interests are aligned in pursuit of common goals of public policy related to the creation and restoration of important facilities and infrastructure of the country.

Korovin (2006) defines PPP as a medium-term or long-term cooperation between the public and the private sector, within which there is a solution to political problems by combining the experience and expertise of several sectors and the financial risks and benefits. By analyzing this definition, we can say that the definition of $E$. Korovin is more suitable to regional projects of PPP in the housing sector, as most of these projects are medium- and long-term, and also there is a solution of socially significant problems in the interaction of government and subjects of housing and communal services.

The World Bank offers a broader view of the rights of private sector and provides the following definition: publicprivate partnership is usually based on an agreement or contract between the state and the private sector for joint infrastructure projects with a possible transfer of ownership of the results to the private sector (World Bank Group, 2008). A similar view is shared by one of the largest consulting companies in the world - Deloitte. Its experts postulate that PPP is a contractual agreement between a government agency and a private company, allowing the latter to increase its participation in the provision of public services (Deloitte Research Study, 2006).

There is a sufficient number of scientists involved in PPPs research, among them are: V.G. Varnavskiy, M.B. Gerard, L.I. Efimov, A.G. Zeldner, V.A. Malygina, V.N. Molchalnikova, A.V. Runova, T. Barnekow, R. Boyle, D. Rich, G.D. Squires, S. Kitajima, F. Cooke, M. Meyer, L. Jezieruski, M. Rustin, A.V. Chernov.

The concept of public-private partnership is ambiguous concept, and is treated differently by many scientists. Barnekow T., R. Boyle, D. Rich argued that the partnership is a mechanism by which the state serves the capital (Barnekov et al., 1990). G.D. Squires (1989) and the Japanese scientist S. Kitajima (1998) conclude that the main goal of the partnership is to maximize the profits of private investors, namely the creation and development of the necessary conditions for improving the performance of large corporations and large-scale industry. P. Cook (1988) and M. Meyer (1994) suggest that the partnership is a mechanism contributing to the development of different classes and categories of society, as they are being directed on the implementation of social projects.

All existing concepts are relevant, but very scattered, none of the considered are complete and neither fully interprets the concept of the term public-private partnership, as well as there is no definition of public-private partnership in the housing sector. PPP projects in each sector of the economy are different, but the utility sector is the most vulnerable, which accounts for over $70 \%$ of the country's economy.

In our view, public-private partnership - is a form of public and private sector interaction that emerges in order to implement socially significant projects, being specific to various industries. Public-private partnership in the field of utility sector (i.e. housing and communal complex) is a balanced interaction between the state and the subjects of housing and communal services with the aim of creating a socially oriented and socially important facilities, providing consumers with necessary and high quality services, improving the economic situation in the country, as well as improving the living standards of the population.

\section{Methodology}

In our opinion the existing scheme of cooperation in projects of public-private partnership in the regional housing sector is not effective and needs to be corrected, because up to now has not brought any results, namely, ongoing projects are not sufficient. The corresponding regulations in public utility sector is still not developed in the regions. Therefore, it is necessary to convert and supplement the existing pattern of interaction, which is being shown in Figure 2 . 


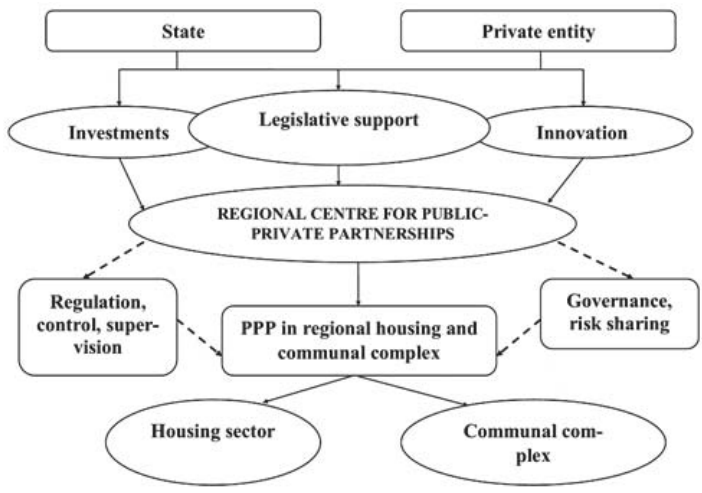

Figure 2. The proposed scheme of PPP interaction in the regional public utility sector

Figure 2 shows that the authors propose to supplement the existing scheme of PPP interactions in the regional utility sector by creating regional development centers in the regions, which will greatly improve the activities in the field of public-private partnership. As practice shows, most regions are not concerned with the effectiveness of the implementation of PPP projects. In some regions of the Russian Federation, it is still possible to find regional centers of PPP development, but their existence is only formal, since they are not involved in the projects themselves. The authors propose to endow regional centers of PPP development with an authority in the field of control, supervision and regulation of such projects, as well as to provide the ability to manage and coordinate the emerging risks that would greatly facilitate the relationship between the state and the subjects of the public utility sector. This operator is needed as to address emerging legal issues that national legislation does not sufficiently take into account, as legal documents in the field of PPP are not sufficient.

\section{Model of PPP Interactions in the Regional Public Utility Sector}

The normal functioning of regional PPP projects requires to determine the public utility forms and mechanisms, management and control bodies and to establish the interaction between the subjects of the public utility sector and the state, as well as to distribute the rights and responsibilities, risks and guarantees between the parties. In this regard, figure 3 reflects the basic forms, models and mechanisms of PPP in terms of their feasibility in the regional public utility sector in more detail.

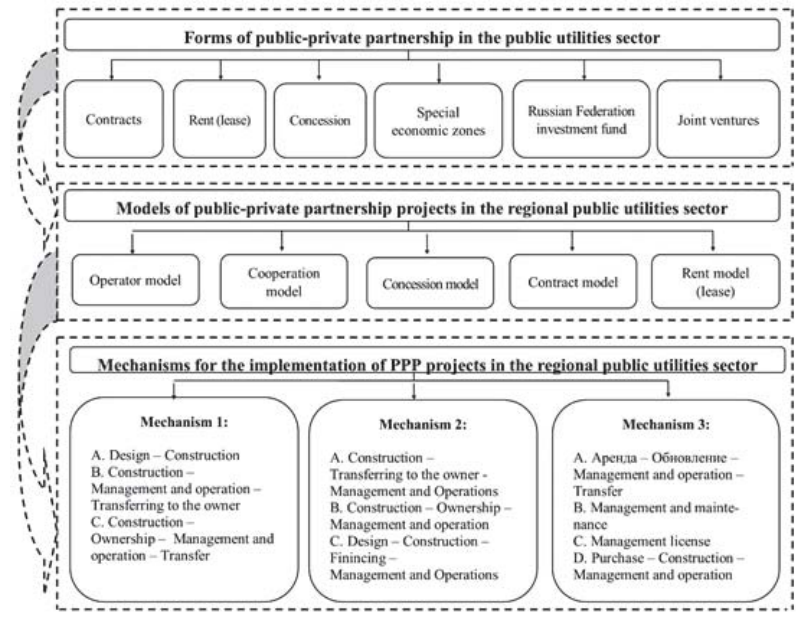

Figure 3. Possible forms, models and mechanisms for the implementation of public-private partnership projects in the regional public utility sector 


\subsection{Forms}

Contracts - signed between the state and the subject of housing and communal services on the implementation of socially significant and socially necessary project or service provision.

Rental relations (i.e. conventional (traditional) or on the terms of lease) - based upon certain contractual conditions, the state transfers the right to manage state or municipal property - the subject of public utility, for a fee, and for a certain time period.

Concession agreements - the most common form of interaction between the state and the subject of public utility to date, being very similar to the lease principal. Namely, the subject of public utility manages the state or municipal property for a fee, and for a certain period of time, but products manufactured or services rendered are the property of the subject public utility, and not the state. The main features of the concession are:

- The property is owned by the state or municipal partner;

- It is a long-term interaction;

- It is implemented for socially significant and socially necessary projects;

- The subject of the concession agreement is not a property of the subject public utility, but the goods produced and services rendered.

Special economic zones - is a separate part of territory which produces special type of business relations aimed at: the development of sectors of the economy, development and production of new products and services, the formation of the transport infrastructure and tourism. Public utility takes the focal point in this process, because in the area of the zone, a functional infrastructure is being created. Namely, the budget funds form the engineering, transport, social and other types of infrastructure. Russian legislation provides the following types of special economic zones: technology development, industrial production, tourism and recreation, and port.

Investment fund of the Russian Federation - predestined to co-finance investment projects, i.e. is part of the federal budget aimed at the development of investment projects on a public-private partnership. The main purpose of this fund is to support the investment attractive and socially significant projects by creating specific infrastructure for each project, without which these projects cannot function. Selection of projects is carried out in public, and selected projects are to be aimed at social development of the region and be the most financially and economically sustainable.

Joint venture - is a company founded by Russian and / or foreign partners, both legal and natural persons of an unlimited number. The main feature of these enterprises is the state's participation in all activities of the enterprise (Filushina, 2013).

\subsection{Models}

Operator model - a clear interaction between the state and the subject of the public utility, namely the distribution of responsibilities and risks between the parties, whereas the function of management and control remains with the state. The main example is this type of partnership is waste processing.

Cooperation model - applies where certain services cannot be fully defined and are poorly marked. Thus, the state and the subject of the public utility implement their own model of interaction in order to determine the object of taxation.

Concession model - as has been described earlier, it is used for the long term projects, as well as in projects where the transfer of ownership is not possible for political and legal reasons.

Contract model - used in projects aimed at reducing costs, and in some projects, the current cost savings of which exceed the investments. The model is most widespread in the projects of interaction between government and stakeholders in the energy sector.

Rent model (lease) - aimed at full confidence in the management of an object of partnership agreement by the subject and is the most common in the construction of socially significant buildings and structures (see Minaev, 2015).

\subsection{Mechanisms}

Mechanism 1:

A. Subject of public utility signs contract with the owner of the land on the design and construction of infrastructure that meets the requirements of the customer. Normally the contract is set for a fixed price. The risks of an increased costs of construction are the sustained with the subject of the public utility.

B. The subject of the public utility takes responsibility for the design, construction, financing and management of 
the facility for a specified period of time. It is responsible to compensates for costs incurred due to the collection of payments for a specified period.

C. Subject public utility does the building and governance of the constructed object as private property within a certain period of time, after which the object becomes the property of the state.

Mechanism 2:

A. In the second model, the subject of public utility executes the construction at the expense of government. Upon completion, ownership is transferred to the state organization that was offering the funding, which can then pass the object in rent to the construction company for a long time. During the period of the lease, the subject of public utility provides operation of the facility and gains profit.

B. Subject of public utility performs the construction, ownership and operation of the facility at its own expense, without transfer of ownership to the state. Projects of this type are similar to the projects of open privatization. In this model, investors require certain safeguards to ensure a return on invested capital.

C. Subject of public utility does the design, finances, and builds new infrastructure and manages the object within a specified period, after which the facility is transferred to state ownership. Investments payback with the payments of the government made for certain services during the project.

Mechanism 3:

A. Applies to the updated (i.e. modernized) objects. Subject of public utility performs the renovation, repair and modernization of objects. In return, it is entitled to rent and operate an object while obtaining the fee for the services provided within a certain period of time.

B. Based on a contract signed with the authorities, the subject of the public utility manages the government owned property for a specified period of time and under certain conditions, while the property remains to be owned by the government.

C. The subject of the public utility is granted a license or right to operate in the sphere of public services for a specified period of time.

D. The model of sale of the operating public utility object by the authorities given that the object will be modernized or repaired. The subject of public utility executes the improvements necessary for the effective management of the facility.

\section{Conclusion}

Based on the proposed PPP scheme implemented in regional public utility sector, authors suggest there are sufficient numbers of forms, models and mechanisms of PPPs and each project has its own model of functioning and implementation. Of course, this is not a complete list of PPP models in the regional public utility sector, as each project is unique in nature and can combine multiple models of functioning. However, in this article we have tried to reflect the most commonly used models is in the field of housing and communal services.

\section{Acknowledgment}

Article is written within the public task of the Russian Ministry № 577 "Research of regularities in managerial processes in the increase of energy efficiency and economic feasibility by introducing energy saving technologies in housing and utilities sector"

\section{References}

Barnekov, T., Boyle, R., \& Rich, D. (1989). Privatism and Urban Policy in Britain and the United States. Oxford.

Chernov, A.V. (2010). Public-private partnership in the field of low-rise housing. Real Estate and Investments. Legal regulation, 4 (45), 39-42.

Cooke, P. (1988). Municipal Enterprise, Growth Coalitions, and Social Justice. Local Economy, 3.

Deloitte Research Study (2006).Closing the Infrastructure Gap: The Role of Public-Private Partnerships.

Filushina, K.E. (2011). New approaches in identifying and managing the risks of the building complex of the region in the context of public-private partnerships. Problems of Modern Economics, 4, 473-478.

Filushina, K.E. (2012a). Risk management in investment and construction projects in the region on the basis of public-private partnerships. PhD thesis: Saint-Petersburg State University of Architecture and Civil Engineering. St. Petersburg.

Filushina, K.E. (2012b). Model of public-private Partnership, which was in the construction industry in the region. Proceedings of the Conference SIC sociosphere, 28, 180-182. 
Filushina, K.E. (2013). Risk management in investment and construction projects in the region on the basis of public-private partnerships (for example, the Tomsk region). Tomsk: Tomsk State University of Architecture and Building.

Filushina, K.E. (2014). Risks arising from the implementation of energy efficiency programs in the residential complex. Scientific Review, 8-1, 397-400.

Jezieruski, L. (1990). Neighborhood and Public-Private Partnerships in Pittsburgh. Urban Affairs Quarterly, 2, 217-249.

Kitajima, S. (1998). Industrial and Regional Restucturing and Changing Form of State Intervention: The Development of Partnerships in Postwar Japan. International Journal of Urban and Regional Research, 1.

Korovin, E. (2006). Credit risk projects of public-private partnerships and support mechanisms. Speech at the round table "Federal support tools investors". Site "regionalism". [Online] Available: http://regionalistica.ru/project/investproject/fed_instr. (February $25,2015)$.

Meyer, M. (1994). Post-Fordist City Politics. Post Fordism. Oxford.

Minaev, N.N. (2014). Development of the priority areas and indicators of housing and communal complex regions. Russia's economic revival, 3 (41), 130-137.

Minaev, N.N. (2015). The Matrix scenario management options zhilschno-municipal complex cities of Russia. Regional economy: theory and practice, 2 (277), 56-66.

O'Toole, L. (1997). The Implications for Democracy in a Networked Bureaucratic World. Journal of Public Administration Research and Theory, 7.

Rhodes, R., \& Marsh, D. (1992). Policy Network in British Politics. A Critique of Existing Approaches. Policy Network in British Government. Oxford.

Rustin, M. (1989). The Politics of Post-Fordism: Or, the Trouble with New Times. New Left Review, 175, 54-77.

Squires, G.D. (1989). Public-Private Partnerships: Who Gets What and Why. Unequal Partnerships: The Political Economy of Urbana. Development in Postwar America. New Brunswick.

Varnavskiy, V.G. (2005). The privatization processes in the infrastructure: successes and failures of reform. World Economy and International Relations, 8, 109-113.

World Bank Group (2008). Private Participation in Infrastructure Projects Database: The Public-Private Infrastructure Advisory Facility. [Online] Available: http://ppi.worldbank.org_(February 15, 2015).

Yakunin, V. (2007). Partnership in the mechanism of governance. Sociological studies, 2. 
